districts. An earlier protection time in spring would save many breeding lobsters, and extension to later in autumn would bring with it a better quality of fish.

The breeding experiments at Flødevigen are carried on in view of the fact that by increasing the number of young by enclosing a mother lobster, hatching the eggs in captivity and rearing the young to the bottom stage, an increase of lobster stock will be effected, for in this way the larval stages which are the most exposed to dangers are protected for the most susceptible time of their life. The lobsterlings when they have attained the bottom stage are set free into the sea. A technique has now been evolved which is very sure, and one can reckon on an output of 20-40 per cent. It is now possible to bring lobster young from the egg to the bottom stage in so great numbers that it is undoubtedly valuable in increasing the stock. This technique has been described in Dannevig's former paper "The Rearing of Lobster Larvæ at Flødevigen" (1928). The technique being established, it is now only a question of how cheaply the whole of the rearing and transport can be effected. There is every ground for believing that it is possible to bring working expenses of production down to a fractional part of the present amount. The plans for the immediate future include still further research in those areas where the young are released. So far, the rearing experiments have prospered. Important results should follow these successes.

\title{
Petroleum and Petroleum Products
}

$\mathrm{T}$ HE group of papers on conservation of petroleum and natural gas given at the third World Power Conference forms the subject of a report by $\mathrm{H}$. C. Fowler (Section IV, Paper No. 12). Mr. Fowler stressed the principle enunciated by Sir John Cadman that petroleum should not be produced without adequate need, having regard to the vital part played by crude petroleum in the life of civilized communities to-day, and the view held by technicians that resources of crude petroleum are not unlimited. The problem of conservation presents a different aspect in each oil-producing country, and it is difficult to assess it from the point of view of world resources. In the case of the United States of America, the problem is unique and the ultimate policy adopted there will probably have a greater influence on the world petroleum industry as a whole than that of all other oil-producing countries combined.

Before effective measures for world conservation can be adopted, however, there are certain preliminary investigations to be made. The extent and character of waste production in countries having relatively large portions of known oil resources should be determined and note taken of methods employed to conserve resources under specific conditions. In those countries which depend chiefly on imported supplies of oil, the problem should be regarded from the point of view of conservation of utilization. Further, organization of the industry in different countries should be surveyed from the point of view of the effect of property laws, State regulations, etc. Finally, the uses of petroleum should in every case be justified or otherwise, and decisions on this point taken only with full cognisance of all possible sub. stitutes for petroleum and a knowledge of their specific uses. These and other economic factors which are bound to affect utilization and conservation of petroleum should be carefully weighed before judgment is passed on the whole problem of how best to use or conserve this commodity, which now seems indispensable to modern industrial life, but is at the same time believed to be capable of exhaustion.

In his general report (Section II, Paper No. 6) on papers submitted at the Conference on the organization of the production, transportation and distribution of natural and manufactured gas, E. R. Weaver directed attention to the marked contrast between European and American practices within the gas industry. The contrast is chiefly attributable to the greater abundance and variety of fuels obtain. able in America, and to different legal and financial factors within the industry. Moreover, in practically every European country, distribution of adequate gas supplies is undertaken by public bodies, whereas in the United States of America public interest is for the most part not represented on the boards and councils of gas concerns. Large holding companies, therefore, compete with each other for areas of supply and are not responsible for their policies to any higher authority. This fact cannot be said to further ultimate national conservation of this commodity in America.

In the case of European countries, a strikingly similar development of the gas industry appears to have taken place in each of them, and such differences as exist are rather differences in stages of development than fundamental dissimilarities. Germany is at present pursuing an advanced policy of consolida. tion, the professed ideal being delivery of gas to every station at every moment as economically as possible, and also at the same time withdrawal from each producing unit of an allotted quota. To achieve this, not only daily but also hourly load of every pipe has to be calculated and attention given to weather reports and other factors likely to influence gas sales. The question now being debated by technicians is whether fundamental conditions exist in other European countries which will prohibit a similar national programme of gas economy to that aimed at by Germany.

E. B. Swanson gave a general report (Section II, Paper No. 5) on papers in connexion with present-day organization of the petroleum industry. The industry may be said to comprise five structural components: exploration, production, transportation, manufacturing and distribution. The degree of economic stability attainable by an individual country or company is dependent largely upon the extent to which it is possible for it to enter into all five branches of the industry's activities. Papers descriptive of the organization of the petroleum industry in the Argentine, Austria, Canada, China, France, Germany, Great Britain, Hungary, Poland and the United States, substantiate this fact, and at the same time facilitate classification of these countries into four categories : producer; producer-refiner-marketer ; purchaser-refiner-marketer ; and purchaser-marketer. 
The ultimate aim of each country is to engage in all branches of the industry and to attain a balanced degree of activity in each branch.

Several factors, however, determine the status of individual countries and/or units within the industry. The most important of these are the extent to which the indigenous supply of crude petroleum is capable of fulfilling the demand for petroleum products within a country; problems of general industrial organization and the extent and influence of governmental control or assistance. In turn, the degree to which governmental influence is exerted or withheld is based on the particular growth of the industry within each country. Far-reaching governmental control and stringent legislation will be found to operate in those countries where there has arisen progressive lack of balance between indigenous supply and home demand, lack of stabilization of markets through nonparticipation of lesser units, or other economic maladjustments.

\section{The Bushman Skull}

\section{$\mathrm{I}^{\mathrm{N}}$} the course of a discussion of the significance of the Bushman skull (Soölogiesa Navorsing v. die Nas. Mus., Bloemfontein, 1, 3-4), Dr. T. F. Dreyer contends that the genus Homo at a very early date evolved along three independent lines-Neanderthal, the Eurasian and the Bushman. The Bushman, in the smallness and orthognathism of the face, the steepness of the forehead, and the flatness of the dorsal profile, shows features, in which it resembles the juvenile skull. It is here suggested that this 'foetalization' (Bolk) is not due to an adult retention of juvenile features, but is a precocious assumption of the adult. This explains the fact that a Bushman baby of about twelve months is already a Bushman, and differs distinctly from the babies of other races, as does the adult Bushman from other adults. This difference is thus due to the projection of adult features into the earlier ontogenetic stages.

The typical orthognathism of the Bushman skull, after a period of prognathism which lasts for some months after birth, is extreme up to six years and then is less pronounced in maturity. This is a result of two growth processes, the peak of jaw formation falling within the foetal period, while the upper face, correlated with the growth of the base of the brain, grows more rapidly during the first six years after birth. The eranial form, with characteristic bulging of the forehead and flatness of the dorsal profile, is due to the differential growth of the roof and floor of the brain; there being a lack of growth of the anterior end of the base, while the roof grows very slowly during foetal life, very rapidly during the first two years after birth, and then keeps pace with the floor of the brain until maturity is reached.

Modern miscegenation with Bantu produces a small brain and a long face (Baralong), but early crosses of Bushman with a Hottentot-like race (Matjes River) produced a large brain with a small face. In both cases the proximate cause appears to be a disturbance in the functioning of the pituitary gland. The sella turcica in the Bush-Bantu is abnormally large - the first case recorded of hypertrophy of the pituitary in an African-while in Bush skulls the sella tureica is abnormally small.

Hybridization with the Bushman would thus seem to set up a disturbance of hormonic control, with the result that one or other set of racial characters becomes exaggerated. It remains to be determined whether the differences between the Bushman and other groups of Homo sapiens are of such a degree of importance that most important physiological disturbances result from hybridization, and are of sufficient weight to demand the separation of the race from $H$. sapiens as a distinct species.

\section{Work of the Rothamsted Experimental Station}

\begin{abstract}
TN studying the annual report for 1935 of the 1 Rothamsted Experimental Station*, it is impossible not to be impressed by the number and value of the experiments carried out at this institution in co-operation with various bodies and individuals. If the British farmer and his trading associates are averse to co-operation in commerce, they have not proved to be so in the field of research directed from Rothamsted. One of the fruits of bringing together producer and expert buyer has been progress in the direction of understanding 'quality', as applied to some agricultural products.

A series of fertilizer experiments, carried out with the help of the sugar-beet factories, and planned at the Statistical Department at Rothamsted, has the object of putting the manuring of this crop on a

* Rothamsted Experimental Station: Lawes Agricultural Trust. Report for 1935. Pp. 279. (Harpenden : Rothamsted Experimental Station, 1936.) $28.6 d$.
\end{abstract}

sound and more accurate basis. Trials carried out in Great Britain indicate that this crop does not give the response to various manures that might be expected from Continental experience. In the trials directed from Rothamsted, not only is the effect of fertilizers carefully assessed, but also an elaborate examination of the soil is in progress, in order to correlate soil properties and fertilizer responses. This erop is also the subject of trials at Rothamsted and Woburn, arranged under the ægis of the Ministry of Agriculture and of the sugar-beet factories. These trials are designed to measure the effects of spacing, and of sulphate of ammonia applied at different spacings; the results at both centres indicate that nitrogen produces a greater effect in the narrower rows.

Useful information was gathered from conferences of growers of malting barley; these took the form 